\title{
Cerebellar Vermis: Topography and Variations
}

\author{
Vermis Cerebelar: Topografía y Variaciones
}

\author{
"Rodrigo Freitas Monte Bispo; ${ }^{* *}$ Antonio José Casado Ramalho; ${ }^{* *}$ Luiz Carlos Buarque de Gusmão; ${ }^{* *}$ Amundson Portela \\ de Holanda Cavalcante; ${ }^{* * *}$ Amauri Clemente da Rocha $\boldsymbol{\&}^{* * * *}$ Célio Fernando de Sousa-Rodrigues
}

\author{
BISPO, R. F. M.; RAMALHO, A. J. C.; GUSMÃO, L. C. B.; CAVALCANTE, A. P. H.; ROCHA, A. C. \& SOUSA-RODRIGUES,C. \\ F. Cerebellar vermis: topography and variations. Int. J. Morphol., 28(2):439-443, 2010.
}

SUMMARY: The vermis is described as the unpaired, median portion of the cerebellum to which the hemispheres are attached. Both the vermis and the hemispheres are formed by folia that, grouped together, are called lobules. The material analyzed consisted of a sample made up of 43 adult male cerebella fixed in $10 \%$ formaldehyde and sliced medially. The lingula was attached to the superior medullary velum in $100 \%$ (43) of the cerebella, varying only in size. In $80 \%$ (32) of the cerebella, the central lobe contained one folium; $7.5 \%$ (3) had two folia with the first larger than the second; $10 \%$ (4) had two folia with the second larger than the first; and 2.5\% (1) had two folia of equal size. In 5\% (2) of the cerebella, the folium of the vermis emerged from the declive; in 47.5\% (19), the folium emerged from the central white matter; and in $42.5 \%$ (17), the folium emerged from the tuber. There was no variation in the lobules, culmen, pyramid, uvula or nodule in the sample studied. Contrary to what many believe, the folia of the cerebellum exhibit variations in form, number and arrangement. However, these variations are virtually unreported, which often hinders the determination of the limits of these structures by students of anatomy of the cerebellum.

\section{KEY WORDS: Cerebellum; Vermis; Variation.}

\section{INTRODUCTION}

Macroscopically, the cerebellum has a median, unpaired portion known as the vermis, which is united to two lateral masses denominated cerebellar hemispheres. Its weight is between 140 and $150 \mathrm{~g}$. Its entire surface has both shallow (grooves) and deep (fissures) depressions, which limit various thin laminae to the folia of the cerebellum. These laminae group to form the lobules of the vermis and hemispheres. The cerebellum is commonly described as phylogenetically divided into archicerebellum, paleocerebellum and neocerebellum, which have the following three functions:

1. Maintenance of balance through the inner ear, which contains balance receptors. The innermost region, which is also called the boney and membranous labyrinth, is enervated by the vestibular branch of the vestibulocochlear nerve (8th cranial pair), which consists of the ampullar, utricular and saccular nerves. These nerves transmit information on the position of the head in space to the archicerebellum, which makes the necessary adjustments. As this part of the cerebellum has connections with the vestibular region of the inner ear, the archicerebellum may be called the vestibular cerebellum (Tortora \& Grabownski, 2002).

2. Maintenance of muscle tonus; regulation of gait, gross motor movements and symmetrical movements. In order to regulate these movements, the cerebellum receives information on muscle activity, which is known as unconscious proprioception. As this part of the cerebellum has connections with the spinal cord, the paleocerebellum may be called the spinal cerebellum (Machado, 1993).

3. Coordination of fine motor movements, such as playing a piano or writing. These more elaborate movements related to body perception, muscle activity and joint movements are denominated conscious proprioception. As this part of

\footnotetext{
* Human Anatomy, Universidade Estadual de Ciências da Saúde de Alagoas and Faculdade Integrada Tiradentes, Maceió, Brazil

** Department of Morphology, Centro de Ciências Biológicas, Universidade Federal de Alagoas, Maceió, Brazil

*** Department of Morphology, Universidade Federal de Alagoas and Universidade Estadual de Ciências da Saúde de Alagoas, Maceió, Brazil
} 
the cerebellum has connections with the cerebral cortex, the neocerebellum may be called the cortical cerebellum (Snell, 2003).

Bower \& Parsons (2003) report other functions that make up the cerebellum, such as perception and cognition as well as playing an important role in short-term memory, attention, control of impulsive acts, emotions, upper cognitive functions, ability to plan tasks and possibly even conditions such as schizophrenia and autism. Kandel et al. (1991) state that one of the main functions of the cerebellum is to adjust the output of the motor system, comparing intention with performance and compensating for errors in movements. Some characteristics of the organization of the cerebellum described below:

1. The cerebellum receives information from brain structures involved in the planning and execution of movement. In this type of feedback, for example, neurons from the motor and pre-motor cortex project their axons to different regions of the cerebellum. The cerebellum monitors control signals from motor spinal neurons and integrates peripheral and descending information in the spinal cord.

2.The cerebellum receives information on motor performance through sensory feedback stemming from the periphery during the execution of movement. These internal and external signals allow the cerebellum to establish a comparison of the information with the actual motor response.

Anatomists have identified 10 different lobules. Although their names do not need to be learned, one set of lobules is clinically important - the cerebellar tonsils, which are situated below the cerebellum. The tonsils often undergo injury when a mass in a brain hemisphere (such as a tumor or hemorrhage) displaces the brain stem and descending cerebellum through the magnum foramen (tonsillar herniation).
There are eight lobules in the hemispheres: wing of the central lobule, anterior quadrangular lobule, posterior quadrangular lobule, superior semilunar lobule, inferior semilunar lobule, biventral lobule, tonsil and floccule. There are nine lobules of the vermis: lingula, central lobule, culmen, declive, folium of the vermis, tuber, pyramid, uvula and nodule. These lobules are often difficult to observe during practical human anatomy classes and may vary in size, shape and number of folia. In the frame below, the lobules of the vermis are related with those of the hemispheres, except for the lingula, which is not related with any lobule of the hemispheres, but rather with one of the structures that forms the roof of the 4th ventricle, denominated the superior medullary velum.

It is difficult to identify the lobules of the vermis mainly due to variations and a lack of literature describing common findings in these lobules. For example, the following authors do not describe any type of variation in the cerebellar vermis: Bouchet \& Cuilleret (1978); Heidegger (2000); Kandel et al.; Lockhart et al. (1983); Romer \& Parsons (1985); Young \& Young (1998); House \& Pansky (1962); Noback et al. (1999); Di Dio (2002); Tortora \& Grabowski; Moore (2007); Monkhouse (2004); Gardner et al. (1988); Goss (1988); Latarjet \& Ruiz Liard (1993); Testut \& Latarjet (1960); Williams \& Warwick (1995); Machado; and Snell.

The aim of the present study was to determine morphological variations in the lobules of the cerebellar vermis.

\section{MATERIAL AND METHOD}

Forty-three cerebella from male and female adults were obtained (fixed in $10 \%$ formaldehyde) from the laboratories of the Descriptive and Topographic Anatomy Division of the Universidade Federal de Alagoas and Universidade Estadual de Ciências da Saúde de Alagoas

\begin{tabular}{lll}
\hline Lobules of the Vermis & Lobules of the Hemispheres & Division of the Cerebellum \\
\hline Lingula & - & Paleocerebellum \\
Central lobule & Wing of lobule central & Paleocerebellum \\
Culmen & Anterior quadrangular lobule & Paleocerebellum \\
Declive & Posterior quadrangular lobule & Neocerebellum \\
Folium of the vermis & Superior semilunar lobule & Neocerebellum \\
Tuber & Inferior semilunar lobule & Neocerebellum \\
Pyramid & Biventral lobule & Paleocerebellum, neocerebellum, respectively \\
Uvula & Tonsil & Paleocerebellum, neocerebellum, respectively \\
Nodule & Floccule & Arquicerebellum \\
\hline
\end{tabular}


(Brazil). The protocol involved a median section of the vermis. Possible variations in the size, shape and number of folia in the lobules of the vermis were investigated.

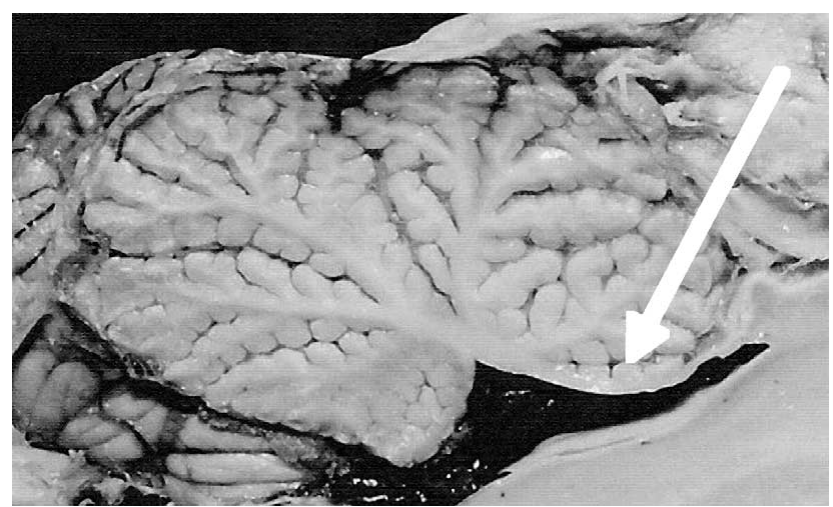

Fig. 1. Lingula attached to superior medullary velum (arrow).

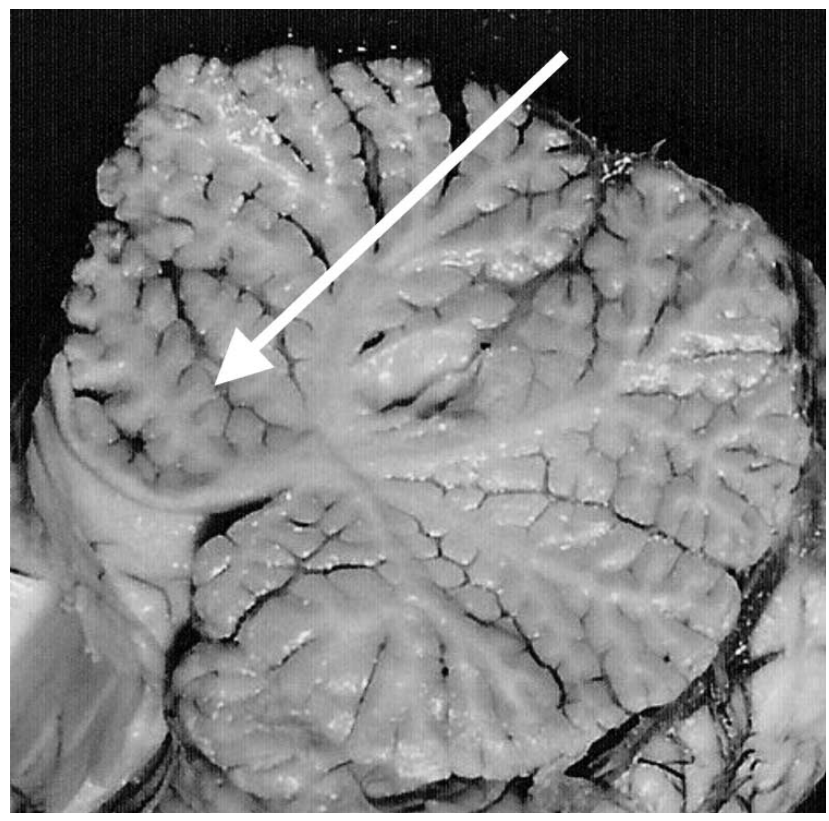

Fig. 2. Central lobule with two folia (arrow), the first of which is larger.

\section{RESULTS AND DISCUSSION}

The lingula is the first lobule of the upper portion of the vermis on the superoinferior axis and pertains to the paleocerebellum, together with the central lobule, culmen, pyramid and uvula. It is separated from the central lobule by the pre-central fissure. The lingula is also the only part of the vermis that is not related to any lobule of the hemispheres. Although Machado states that the lingula is nearly always attached to the superior medullary velum, in the sample

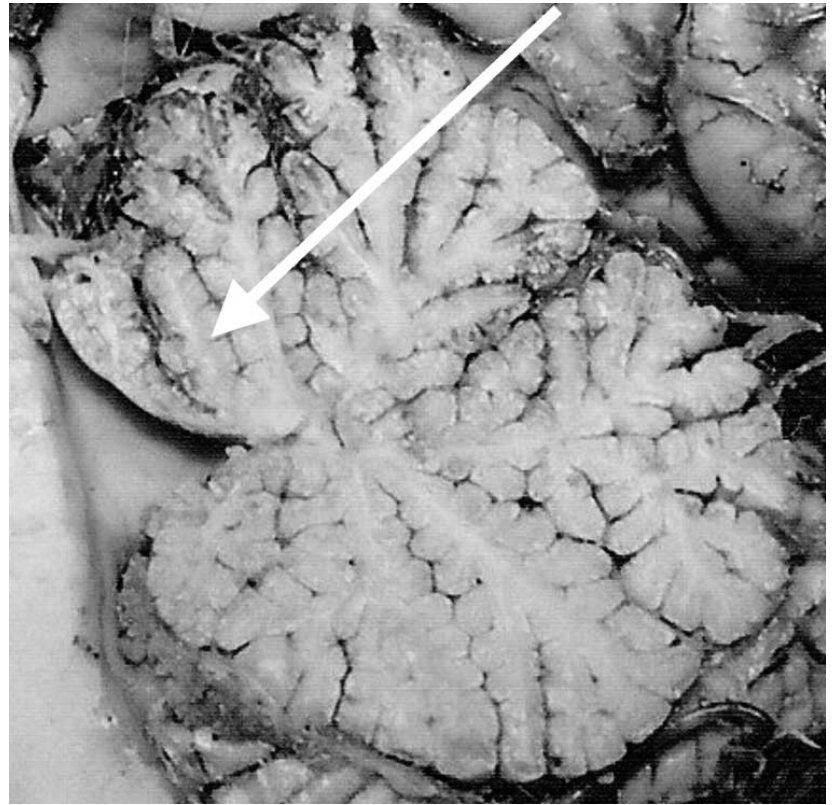

Fig. 3. Central lobule with two folia (arrow), the second of which is larger.

studied, it was attached to the superior medullary velum in $100 \%$ (43) of the cerebella (Fig.1), varying only in size. Latarjet \& Ruiz-Liard (1993) state that the base of the superior medullary velum underlies the lingula.

The central lobule is the second lobule of the upper portion of the vermis on the superoinferior axis. It is separated from the culmen by the pre-culminal fissure and is related with the wing of the central lobule pertaining to the hemisphere. When the lingula is damaged and the central lobule has two folia, the first folium is often confused with the lingula. There are divergences in the drawings in anatomy books regarding this lobule. For example, Snell, Williams \& Warwick, Goss and Latarjet \& Ruiz Liard describe the central lobule as having a single folium, whereas Machado (1993), Testut \& Latarjet, and Heidegger state that the central lobule has two folia. In the present study, $32(80 \%)$ of the cerebella had a central lobule with one folium (Fig. 2); three (7.5\%) had a central lobule with two folia, the first of which was larger than the second; four $(10 \%)$ had a central lobule with two folia, the second of which was larger; and one (2.5\%) had a central lobule with two folia of equal size.

The culmen is the third and largest lobule of the upper portion of the vermis on the superoinferior axis. It is separated from the declive by the primary fissure and is related with the anterior quadrangular lobule of the hemisphere. The culmen exhibited no variation in size in the present study. 


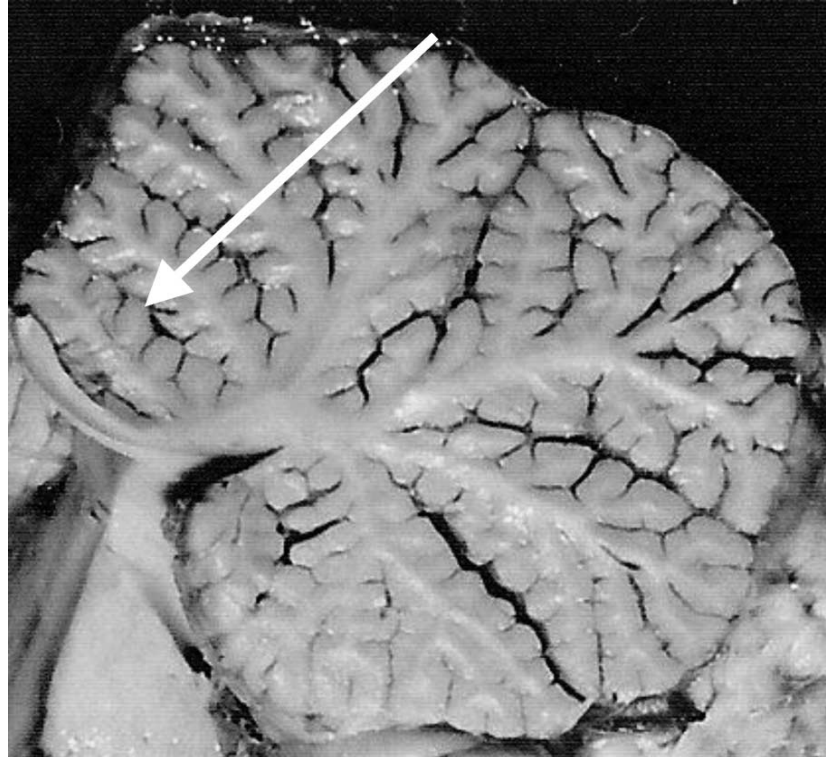

Fig. 4. Central lobule with two folia of equal size (arrow).

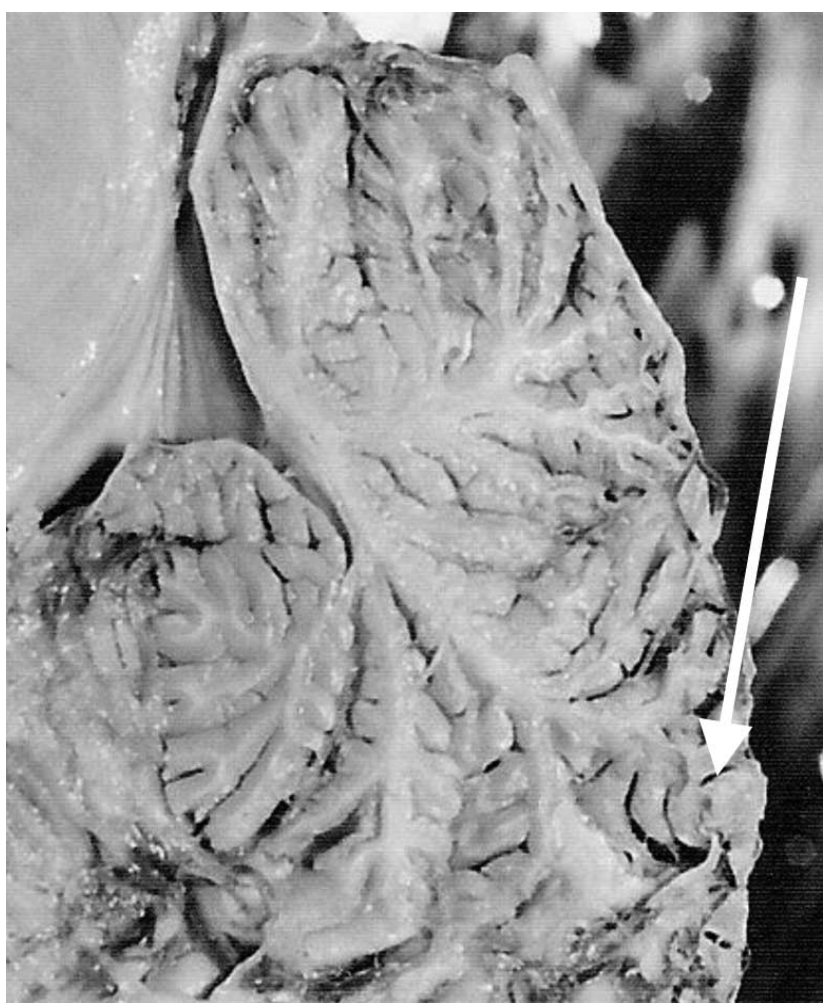

Fig. 5. Folium of the vermis emerging from the declive (arrow).

The declive pertains to the neocerebellum. It is separated from the folium by the post-clival fissure and is related with the posterior quadrangular lobule. The folium emerged from the declive in two $(5 \%)$ of the cerebella (Fig. 5).

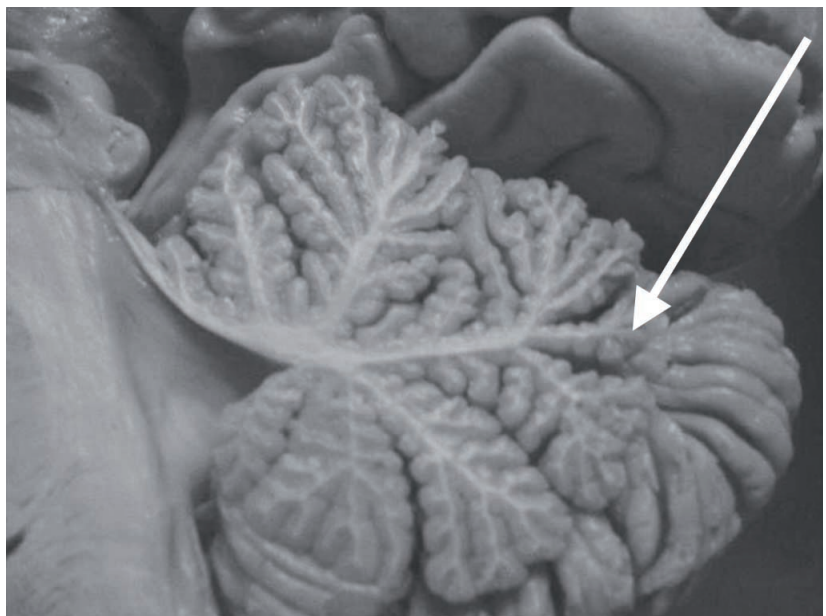

Fig. 6. Central lobule containing one folium and folium of the vermis emerging from the central white matter.

The folium of the vermis is one of the smallest lobules of the vermis. It is separated from the tuber by the horizontal fissure and is related with the superior semilunar lobule. In $19(47.5 \%)$ of the cerebella, the folium emerged from the central white matter.

The tuber is related with the inferior semilunar lobule. In 17 (42.5\%) of the cerebella, the folium of the vermis emerged from the tuber, which corroborates the finding described by Snell.

The pyramid is the seventh lobule of the vermis on the superoinferior axis. It is separated from the tuber and uvula by the pre-pyramidal and secondary fissures, respectively. This lobule is related with the biventral lobule of the hemisphere. The pyramid exhibited no variation in the present study.

The uvula is the second largest lobule, following the culmen. It pertains to the paleocerebellum and is separated from the nodule by the posterolateral fissure. The uvula exhibited no variation in the present study.

Contrary to what many believe, the folia of the cerebellum exhibit frequent variations in form, number and arrangement. However, these variations are virtually unreported, which often hinders the determination of the limits of these structures by students of anatomy of the cerebellum. 
BISPO, R. F. M.; RAMALHO, A. J. C.; GUSMÃO, L. C. B.; CAVALCANTE,A.P. H.; ROCHA,A. C. \& SOUSA-RODRIGUES,C. F. Vermis cerebelar: topografía y variaciones. Int. J. Morphol., 28(2):433-438, 2010.

RESUMEN: El vermis se describe como la parte impar, mediana del cerebelo por la que los hemisferios están conectados. Tanto el vermis como los hemisferios están formados por folium que, de forma conjunta, se llaman lóbulos. El material analizado consistió en una muestra compuesta por 43 cerebelos de hombres, adultos, fijados en formol al $10 \%$ y cortados en rodajas en sentido medial. La língula se adjuntó al velo medular superior en $100 \%$ (43) del cerebelo, y sólo varían en tamaño. En el 80\% (32) del cerebelo, el lóbulo central contenía un folium, 7,5\% (3) había dos folium con el primero más grande que el segundo, 10\% (4) tuvo dos folium con el segundo más grande que el primero, y 2,5\% (1) tenía dos folium de igual tamaño. En el 5\% (2) de los cerebelos, el folium del vermis surgido del declive, en el 47,5\% (19), el folium surgido de la sustancia blanca central, y en el 42,5\% (17), el folium surgido del tubérculo. No hubo, en la muestra estudiada, variación en los lóbulos, culmen, pirámide, úvula o nódulo. Contrariamente a lo que muchos creen, el folium del cerebelo presentan variaciones en la forma, número y disposición. Sin embargo, estas variaciones son virtualmente inadvertidas, lo que a menudo dificulta la determinación de los límites de estas estructuras del cerebelo, por los estudiantes de la anatomía.

PALABRAS CLAVE: Cerebelo; Vermis; Variación anatómica.

\section{REFERENCES}

Bouchet, A. \& Cuilleret J. Anatomía Descriptiva, Topográfica y Funcional. Buenos Aires, Medica Panamericana, 1978.

Bower, J. M. \& Parsons, L. M. O cerebelo reconsiderado. Revista Scientific American Brasil, 2(16):66-73, 2003.

Di Dio, L. J. A. Tratado de Anatomía Sistémica Aplicada. $2^{\mathrm{a}}$ Ed. São Paulo, Atheneu, 2002.

Gardner, E.; Gray, D. J. \& O’Rahilly, R. Anatomía. $4^{\mathrm{a}}$ Ed. Rio de Janeiro, 1988.

Goss, C. M. Anatomía de Gray. $29^{\circ}$ Ed. Rio de Janeiro, Guanabara-Koogan, 1988.

Heidegger, G. W. Atlas de Anatomía Humana. $3^{\circ}$ Ed. Rio de Janeiro, Guanabara-Koogan, 2000.

House, E. L. \& Pansky, B. Neuroanatomía. Lopez, Buenos Aires, 1962.

Kandel, E. R.; Schwartz, J. H. \& Jessell, T. M. Principles of Neural Science. $3^{\text {a }}$ Ed. Prentice-Hall International Inc, 1991.

Latarjet, M. \& Ruiz Liard, A. Anatomia Humana. $2^{\text {a }}$ Ed. São Paulo, Panamericana, 1993. V.1.

Lockhart, R. D.; Hamilton, G. F. \& Fyfe, F. W. Anatomia do Corpo Humano. $2^{\mathrm{a}}$ Ed. Rio de Janeiro, Guanabara Koogan, 1983.

Machado, A. B. M. Neuroanatomía Funcional. $2^{\text {a }}$ Ed. Rio de Janeiro, Atheneu, 1993.

Monkhouse, S. Anatomía Clínica. Rio de Janeiro, Guanabara Koogan, 2004.
Moore, K. L. Anatomía Orientada para a Clínica. $5^{\circ}$ Ed. Rio de Janeiro, Guanabara-Koogan, 2007.

Noback, C. R.; Strominger, N. L. \& Demarest, R. J. Neuroanatomía. 5a Ed. Premier, São Paulo, 1999.

Romer, A. S. \& Parsons, T. S. Anatomía Comparada dos Vertebrados. São Paulo, Atheneu,1985.

Snell, R. S. Neuroanatomía Clínica. 5a Ed. Rio de Janeiro, Guanabara Koogan, 2003.

Testut, L. \& Latarjet, A. Tratado de Anatomía Humana. Barcelona, Salvat, 1960.

Tortora, G. J. \& Grabowski, S. R. Princípios de Anatomía e Fisiología. 9a Ed. Guanabara Koogan, Rio de Janeiro, 2002.

Williams, P. L.; Warwick, R.; Dyson, M. \& Bannister, L. H. Anatomía de Gray. $37^{\circ}$ Ed. Rio de Janeiro, GuanabaraKoogan, 1995.

Young, P. A. \& Young, P. H. Bases da Neuroanatomia Clínica. Guanabara Koogan. Rio de Janeiro, 1998.

Correspondence to:

Prof. Dr. Célio Fernando de Sousa Rodrigues

Disciplina de Anatomia Humana

Universidade Estadual de Ciências da Saúde de Alagoas UNCISAL

Rua Jorge de Lima, 113

CEP: $57010-300$

Trapiche, Maceió-AL,

BRAZIL

Received: 18-10-2009

Accepted: 22-02-2010 
